\title{
Ida Jóźwiak
}

\section{Wina w organizacji jako przesłanka odpowiedzialności podmiotu zbiorowego w świetle projektowanej ustawy o odpowiedzialności}

\author{
podmiotów zbiorowych
}

\begin{abstract}
Streszczenie
Projektowana ustawa o odpowiedzialności podmiotów zbiorowych wprowadza do polskiego porządku prawnego stosunkowo nową podstawę odpowiedzialności, jaką jest wina w organizacji. W porównaniu $\mathrm{z}$ obecnie obowiązującą ustawą, zmieniają się przesłanki uznania organizacji przedsiębiorstwa za nieprawidłową, jak również wprowadzane jest novum w postaci otwartego katalogu przykładowych nieprawidłowości, który potęguje wątpliwości interpretacyjne związane $\mathrm{z}$ rozumieniem pojęcia winy $\mathrm{w}$ organizacji. Do celu wykładni pojęcia nieprawidłowości w organizacji przydatne może być porównanie sposobu organizacji podmiotu zbiorowego ze swoistym modelem „należytej” dla danego podmiotu zbiorowego organizacji, $\mathrm{z}$ uwzględnieniem jego rozmiaru i przedmiotu działalności, podobnie jak ma to miejsce w przypadku wykładni pojęcia należytej staranności. Tworzenie takiego modelu może być jednak kłopotliwe, ponieważ w pierwszej kolejności wymaga określenia optymalnej (z punktu widzenia zapobiegania naruszeniom przepisów prawa) struktury organizacyjnej podmiotu zbiorowego, a następnie oceny związku między sposobem organizacji podmiotu zbiorowego a możliwością lub łatwością popełnienia czynu zabronionego.
\end{abstract}

\section{Wprowadzenie - obecny i projektowany stan prawny}

Odpowiedzialność podmiotu zbiorowego, tj. osoby prawnej lub jednostki organizacyjnej niemającej osobowości prawnej, której odrębne przepisy przyznają zdolność prawną, w tym również spółki handlowej z udziałem Skarbu Państwa, jednostki samorządu terytorialnego lub związku takich jednostek, spółki kapitałowej w organizacji, podmiotu w stanie likwidacji oraz przedsiębiorcy niebędącego osobą fizyczną, z wyłączeniem Skarbu Państwa, jednostek samorządu terytorialnego i ich związków jest na gruncie obecnie obowiązującego stanu prawnego przedmiotem normowania ustawy z 28.10.2002 r. 
o odpowiedzialności podmiotów zbiorowych za czyny zabronione pod groźbą kary¹. Charakterystyczną cechą tej regulacji jest warunek uprzedniego prawomocnego ustalenia odpowiedzialności osoby fizycznej (art. 4 ustawy z 2002 r.), co nadaje odpowiedzialności podmiotu zbiorowego charakteru wtórnego i niesamodzielnego (akcesoryjnego). Jako że zwłaszcza w organizacjach posiadających złożoną strukturę organizacyjną oraz rozbudowane zasady dotyczące podejmowania decyzji ustalenie konkretnej osoby, której można byłoby przypisać odpowiedzialność za popełnienie czynu wskazanego w art. 16 ustawy z 2002 r., obecne unormowania uważane są za nieefektywne².

W związku z powyższym, rząd przygotował projekt nowej ustawy o odpowiedzialności podmiotów zbiorowych ${ }^{3}$, która znacząco rozszerza zakres odpowiedzialności podmiotu zbiorowego $^{4}$ za działania jego pełnomocników, pracowników, współpracowników, podwykonawców, kontrahentów i ich pracowników. Podmiot zbiorowy będzie mógł ponosić odpowiedzialność za wszystkie czyny zabronione pod groźbą kary jako przestępstwo lub przestępstwo skarbowe, a działania lub zaniechania podmiotów działających w imieniu podmiotu zbiorowego będą uznawane za własne zachowania podmiotu zbiorowego. Zgodnie z treścią uzasadnienia, ,projektowana ustawa opiera odpowiedzialność podmiotu zbiorowego zarówno na koncepcji quasi-winy własnej podmiotu zbiorowego, jak i koncepcji tzw. winy anonimowej występującej m.in. w prawie francuskim, niemieckim oraz austriackim"5. Oznacza to rezygnację z obecnego warunku zidentyfikowania konkretnej osoby fizycznej uznanej za sprawcę czynu zabronionego ${ }^{6}$, co bywa problematyczne w organizacjach, w których - jak wskazano powyżej - zaistnienie przestępnego skutku jest rezultatem działania wielu osób, niedziałających jednak wspólnie i w porozumieniu w celach przestępnych.

Abstrahując od dogmatycznych rozważań na temat charakteru prawnego instytucji odpowiedzialności zbiorowej, jak również wątpliwości dotyczących jej dopuszczalności z uwagi na obowiązującą od czasów oświecenia zasadę indywidualizacji odpowiedzialności, niniejszy artykuł ma na celu przeanalizowanie pojęcia winy $\mathrm{w}$ organizacji, wskazanie

\footnotetext{
${ }^{1}$ Dz.U. z 2019 r. poz. 1214, dalej: „obecnie obowiązująca ustawa”; ,ustawa z 2002 r.”.

${ }^{2}$ Uzasadnienie do rządowego projektu ustawy o odpowiedzialności podmiotów zbiorowych, nr projektu: UD74, dostępny na stronie internetowej Sejmu: http://orka.sejm.gov.pl/Druki8ka.nsf/Projekty/8-020-1211-2019/\$file/8020-1211-2019.pdf [dostęp: 15.8.2019].

${ }^{3}$ Rządowy projekt ustawy o odpowiedzialności podmiotów zbiorowych, nr projektu: UD74, dostępny na stronie internetowej Sejmu: http://orka.sejm.gov.pl/Druki8ka.nsf/Projekty/8-020-1211-2019/\$file/8-020-1211-2019.pdf [dostęp: 15.8.2019], dalej: ,projektowana ustawa”.

${ }^{4}$ Definicja podmiotu zbiorowego zawarta w art. 2 pkt 1 projektowanej ustawy jest tożsama z wyżej cytowaną definicją zawartą w art. 2 obecnie obowiązującej ustawy.

${ }^{5}$ Uzasadnienie do rządowego projektu ustawy o odpowiedzialności podmiotów zbiorowych..., s. 4.

${ }^{6}$ Artykuł 3 obecnie obowiązującej ustawy.
} 
problemów związanych ze stosowaniem projektowanych przepisów w praktyce oraz próbę oceny projektowanego modelu odpowiedzialności podmiotów zbiorowych w świetle określonych przez TK zasad stanowienia przepisów o charakterze represyjnym względem podmiotów zbiorowych.

\section{Projektowane przepisy na tle obecnego porządku prawnego}

Za czyn zabroniony w myśl art. 2 pkt 2 projektowanej ustawy rozumie się czyn zabroniony przez ustawę pod groźbą kary, jako przestępstwo ścigane z oskarżenia publicznego lub jako przestępstwo skarbowe, z wyłączeniem czynów popełnionych przez opublikowanie materiału prasowego oraz innych naruszeń prawa związanych z przekazywaniem myśli ludzkiej, do których stosuje się przepisy o odpowiedzialności prawnej i postępowaniu w sprawach prasowych określone w ustawie z 26.1.1984 r. - Prawo prasowe ${ }^{7}$. Oznacza to odejście od przyjętego w obecnie obowiązującej ustawie rozwiązania polegającego na enumeratywnym określeniu katalogu czynów zabronionych ${ }^{8}$, za które podmiot zbiorowy może ponieść odpowiedzialność, co - jak wskazuje T. Darkowski - wpisuje się w coraz bardziej popularny trend, który można określić jako powszechna odpowiedzialność karna podmiotów zbiorowych ${ }^{9}$.

W zakresie podstaw odpowiedzialności w uzasadnieniu projektu ustawy wskazano, że są one uzależnione „od naruszeń reguł ostrożnościowych lub od umyślnego działania osób zobowiązanych do zachowania określonego wzorca postępowania. Są to, między innymi, wina w nadzorze, wyborze czy organizacji, czy wina anonimowa, której projektowane formy zakładają splot trzech czynników - faktu popełnienia czynu, bezpośredniego związku z działalnością przedsiębiorstwa i naruszenia reguł ostrożnościowych"10.

O ile pojęcia winy w nadzorze i winy w wyborze są silnie ugruntowane w doktrynie prawa cywilnego ${ }^{11}$, o tyle nieprawidłowości w organizacji stanowią stosunkowo nowego

\footnotetext{
${ }^{7}$ Dz. U. z 2018 r. poz. 1914.

${ }^{8}$ Art. 16 obecnie obowiązującej ustawy.

9 T. Darkowski, Austriacki model odpowiedzialności karnej podmiotów zbiorowych, Prokuratura i Prawo nr 6 , 2018, s. 7.

${ }^{10}$ Uzasadnienie do rządowego projektu ustawy o odpowiedzialności podmiotów zbiorowych..., s. 5.

${ }^{11}$ Por. m.in.: M. Zelek, Art. 427 [Wina w nadzorze], Art. 429 [Wina w wyborze], [w:] M. Gutowski (red.), Kodeks cywilny. Tom II. Komentarz. Art. 353-626, wyd. 2, Warszawa 2019; W. Borysiak, Art. 427 [Wina w nadzorze], Art. 429 [Wina w wyborze], [w:] K. Osajda, Kodeks cywilny. Tom IIIA. Komentarz. Zobowiązania. Część ogólna, wyd. 22, Warszawa 2019; M. Safjan, Art. 427 [Wina w nadzorze], Art. 429 [Wina w wyborze], [w:] K. Pietrzykowski (red.), Kodeks cywilny. Tom I. Komentarz. Art. 1-44910, Wyd. 9, Warszawa 2018; W. Dubis, Art. 427 [Wina w nadzorze], Art. 429 [Wina w wyborze], [w:] E. Gniewek, P. Machnikowski (red.), Kodeks cywilny. Komentarz, Wyd. 8, Warszawa 2017; P. Machnikowski, A. Śmieja, Art. 427 [Wina w nadzorze], Art. 429 [Wina
} 
rodzaju przesłankę. Wprawdzie obecnie obowiązująca ustawa z 2002 r. w art. 5 pkt 2 również penalizuje sposób „organizacji działalności podmiotu zbiorowego, która nie zapewniała uniknięcia popełnienia czynu zabronionego (...), podczas gdy mogło je zapewnić zachowanie należytej staranności, wymaganej w danych okolicznościach, przez organ lub przedstawiciela podmiotu zbiorowego" ${ }^{12}$, jednakże stosunkowo niewielka liczba postępowań prowadzonych na gruncie tej ustawy (w latach 2013 - 2017 do sądów wpłynęło łącznie jedynie 110 spraw $^{13}$ ) nie sprzyjała dogłębnej analizie tego pojęcia.

Warto jednak nadmienić, że obecnie obowiązująca ustawa była przedmiotem analizy Trybunału Konstytucyjnego, który na wniosek Polskiej Konfederacji Pracodawców Prywatnych, złożony jeszcze przed jej wejściem w życie ${ }^{14}$, badał konstytucyjność jej fundamentalnych przepisów ${ }^{15}$, stanowiących o przyjętym w niej modelu odpowiedzialności. W uzasadnieniu wyroku TK wskazał, że przyjęty w ustawie z 2002 r. model odpowiedzialności nie może być uznany za odpowiedzialność karną sensu stricto, jednak ma charakter represyjny ${ }^{16}$, zaś pojęcie „odpowiedzialności karnej” na gruncie art. 42 Konstytucji musi być interpretowane szerzej aniżeli na gruncie Kodeksu karnego ${ }^{17}$, aby przepis ten nie utracił swojej funkcji gwarancyjnej ${ }^{18}$. Ponadto, zdaniem Trybunału, ,jakkolwiek art. 42 ust. 1 Konstytucji nie wyraża wprost zasady winy, jako przesłanki odpowiedzialności karnej, to zarówno $\mathrm{z}$ procesowej zasady domniemania niewinności określonej w art. 42 ust. 3 Konstytucji, jak i z samej istoty odpowiedzialności represyjnej należy wnosić, że nie powinna być ona nakładana na podmioty, które nie mogły uniknąć popełnienia, ani też zapobiec popełnieniu czynu zabronionego. Innymi słowy, niedopuszczalne jest stosowanie środków

w wyborze], [w:] A. Olejniczak (red.), Prawo zobowiązań-część ogólna. System Prawa Prywatnego. Tom 6, wyd. 3, Warszawa 2018.

${ }^{12}$ Artykuł 5 pkt 2 obecnie obowiązującej ustawy.

13 Zgodnie z treścią uzasadnienia do projektowanej ustawy, w 2017 r. do sądów wpłynęło 14 spraw, w 2016 r. 25 spraw, w 2015 r. - 14 spraw, w 2014 r. - 31 spraw, w 2013 r. - 26 spraw. Uzasadnienie..., s. 1.

${ }^{14}$ Wyrok TK z 3.11.2004 r., K 18/03, OTK-A z 2004 r. z. 10, poz. 103.

15 Przedmiotem analizy Trybunały Konstytucyjnego były:

- zgodność art. 3 obecnie obowiązującej ustawy z art. 2 Konstytucji Rzeczpospolitej Polskiej (dalej: „Konstytucja”),

- zgodność art. 4 w związku z art. 36 ust. 1 obecnie obowiązującej ustawy z art. 2, art. 42 ust. 2 i art. 42 ust. 3 Konstytucji,

- zgodność art. 5 obecnie obowiązującej ustawy z art. 2 i art. 42 ust. 1 Konstytucji,

- $\quad$ zgodność art. 7, 17, 18, 20 i 21 obecnie obowiązującej ustawy z art. 2 Konstytucji,

- zgodność art. 23 obecnie obowiązującej ustawy z art. 42 ust. 3 Konstytucji,

- $\quad$ zgodność art. 33 obecnie obowiązującej ustawy z art. 2 i art. 42 ust. 2 Konstytucji,

- zgodność art. 40 obecnie obowiązującej ustawy z art. 31 ust. 3 i art. 32 Konstytucji,

- $\quad$ zgodność art. 48 obecnie obowiązującej ustawy z art. 2 i art. 42 ust. 1 Konstytucji.

${ }^{16}$ Wyrok TK z 3.11.2004 r., K 18/03, cz. III pkt 2.

${ }^{17}$ Ustawa z 6.6.1997 r. - Kodeks karny, Dz.U. z 2019 r., poz. 1950, t.j.

18 Wyrok TK z 3.11.2004 r., K 18/03, cz. III pkt 2, w którym TK powołał się na swój wcześniejszy wyrok z 8.7.2003 r., P 10/02, OTK ZU nr 6/A/2003, poz. 62 . 
o charakterze represyjnym (penalnym) wobec podmiotu, któremu nie można zarzucić naruszenia prawa, choćby $\mathrm{w}$ postaci zaniechania obowiązkowych działań, które mogły zapobiec popełnieniu czynu zabronionego. Czysto obiektywna odpowiedzialność represyjna, oparta wyłącznie na fakcie odniesienia przez dany podmiot zbiorowy korzyści (lub na możliwości odniesienia takiej korzyści), wykracza poza standardy stanowienia prawa represyjnego w państwie prawa"19.

W kontekście tematyki niniejszego artykułu najbardziej interesujące są jednak rozważania TK dotyczące winy organizacyjnej. Trybunał orzekł, że art. 5 ustawy z 2002 r., który brzmiał wówczas: „Podmiot zbiorowy podlega odpowiedzialności w razie stwierdzenia co najmniej braku należytej staranności w wyborze osoby fizycznej, o której mowa w art. 3 pkt 2 lub 3, lub co najmniej braku należytego nadzoru nad tą osobą albo gdy organizacja działalności tego podmiotu nie zapewnia uniknięcia popełnienia czynu zabronionego, a mogło je zapewnić zachowanie należytej, wymaganej w danych okolicznościach ostrożności przez osobę, o której mowa w art. 3 pkt 1 lub 4"20, w zakresie dotyczącym art. 3 pkt $4^{21}$ tej ustawy jest niezgodny z art. 2 i art. 42 ust. 1 Konstytucji ${ }^{22}$. Innymi słowy, w ocenie Trybunału przepis ustanawiający odpowiedzialność podmiotu zbiorowego za nieodpowiednią organizację, której skutkiem jest popełnienie czynu zabronionego przez osobę fizyczną będącą przedsiębiorcą oraz rzeczywista lub potencjalna korzyść o charakterze majątkowym lub niemajątkowym dla podmiotu zbiorowego, prowadzi do zobiektywizowania odpowiedzialności podmiotu zbiorowego ${ }^{23}$ („nie ma [on] praktycznie możliwości ekskulpowania się od odpowiedzialności za popełniony przez inną osobę czyn zabroniony”24), naruszając tym samym zasadę winy jako przesłankę odpowiedzialności karnej, art. 42 ust. 1 Konstytucji jako standard tworzenia przepisów o charakterze represyjnym i art. 2 Konstytucji jako ogólny standard ustanawiania zasad odpowiedzialności w demokratycznym państwie prawnym.

Jak się wydaje, nieodpowiednią organizację na gruncie art. 5 ustawy z 2002 r. należy rozumieć jako obiektywnie istniejącą w danych okolicznościach możliwość zapobieżenia popełnieniu czynu zabronionego przez osobę fizyczną będącą przedsiębiorcą, gdyby osoba

\footnotetext{
${ }^{19}$ Ibidem, cz. III pkt 5.3 .

${ }^{20}$ Artykuł 5 ustawy z 2002 r. w brzmieniu obowiązującym od dnia uchwalenia ustawy do 29.06 .2005 r. tj. dnia przed dniem utraty mocy obowiązującej przez ten przepis na mocy wyroku TK z 3.11.2004 r., K 18/03.

${ }^{21}$ Zgodnie z tym przepisem, podmiot zbiorowy podlega odpowiedzialności za czyn zabroniony, którym jest zachowanie osoby fizycznej będącej przedsiębiorcą, jeżeli zachowanie to przyniosło lub mogło przynieść podmiotowi zbiorowemu korzyść, chociażby niemajątkową.

${ }^{22}$ Wyrok TK z 3.11.2004 r., K 18/03, cz. I pkt 3.

${ }^{23}$ Ibidem, cz. III pkt 5.5.

${ }^{24}$ Ibidem.
} 
ta zachowała wymaganą ostrożność. Zdaniem Trybunału, „o ile jednak można wskazać pewne kryteria, pozwalające na ocenę, czy organizacja określonego podmiotu minimalizuje ryzyko powstania szkód majątkowych związanych z działaniami podejmowanymi przez ten podmiot (a do tego sprowadza się «wina organizacyjna» w prawie cywilnym), to brak jest takich kryteriów, gdy chodzi o ryzyko popełniania czynów zabronionych przez osoby powiązane organizacyjnie z danym podmiotem, tym bardziej że te czyny zabronione nie muszą łączyć się z wyrządzeniem szkody materialnej" ${ }^{25}$. Niestety Trybunał nie wskazał, jakie są owe „pewne kryteria” oceny prawidłowości organizacji podmiotu zbiorowego.

Warto w tym miejscu odnotować również spostrzeżenia M. Słupskiej i T. Sroki zawarte w glosie do cz. I pkt 3 cytowanego orzeczenia, którzy wysunęli wątpliwość, czy „nie należałoby przyjąć, że ustawodawca przekroczył granice swobody stworzone mu przez Konstytucję i uznać art. 5 ustawy w całości za sprzeczny z art. 42 ust. 1 Konstytucji”26, argumentując ją tym, że ,zgodnie z treścią art. 5 ustawy dla przyjęcia odpowiedzialności podmiotu zbiorowego wystarcza jedynie stwierdzenie braku należytej staranności w wyborze lub nadzorze osoby fizycznej, a także sytuacja, gdy organizacja działalności podmiotu nie zapewnia uniknięcia popełnienia czynu zabronionego. Wystarcza stwierdzenie pewnych obiektywnie występujących nieprawidłowości. Tak więc model odpowiedzialności przyjęty przez ustawodawcę stoi w sprzeczności z art. 42 ust. 1 Konstytucji RP”27. Glosatorzy zauważyli również, że „choć więc w większej części wywód Trybunału wskazuje na sprzeczność sposobu określenia winy $\mathrm{w}$ art. 5 ustawy $\mathrm{z}$ art. 2 Konstytucji, to sentencja wyroku odnosi się tylko do sprzeczności z Konstytucją pewnego zakresu «winy organizacyjnej». Tymczasem, jeżeli cały przepis zostaje uznany przez Trybunał za sprzeczny z ustawą zasadniczą, to konsekwentnie cały powinien być wyeliminowany z porządku prawnego" 28 .

Luka po utracie mocy obowiązującej części art. 5 ustawy z 2002 r. była uzupełniana przez ustawodawcę dwukrotnie ${ }^{29}$. Przepis w obecnym brzmieniu różni się od tego ocenianego przez TK tym, że wina organizacyjna jest oceniana przez pryzmat niezachowania należytej staranności przez organ lub przedstawiciela podmiotu zbiorowego, a w stosunku do osoby fizycznej będącej przedsiębiorcą jako sprawcy czynu zabronionego doprecyzowano,

\footnotetext{
${ }^{25}$ M. Słupska, T. Sroka, Problem zgodności art. 5 ustawy o odpowiedzialności podmiotów zbiorowych z art. $2 i$ 42 ust. 1 Konstytucji. Glosa do wyroku TK z dnia 3 listopada 2004 r., K 18/03, PiP 2005/8/121-126, pkt 2.

${ }^{26}$ Ibidem.

${ }^{27}$ Ibidem.

${ }^{28}$ Ibidem, pkt 3.

${ }^{29}$ Ustawą z 28.7.2005 r. o zmianie ustawy o odpowiedzialności podmiotów zbiorowych za czyny zabronione pod groźbą kary, Dz.U. z 20.09.2005 r. nr 180 poz. 1492 oraz ustawą z 29.7.2011 r. o zmianie ustawy - Kodeks karny, ustawy - Kodeks postępowania karnego oraz ustawy o odpowiedzialności podmiotów zbiorowych za czyny zabronione pod groźbą kary, Dz.U. z 13.9.2011 r. Nr 191, poz. 1135.
} 
MŁODY JURYSTA 2019/3

że musi to osoba, która bezpośrednio współdziałała z podmiotem zbiorowym w realizacji celu prawnie dopuszczalnego ${ }^{30}$.

\section{Pojęcie winy w organizacji na gruncie projektowanej ustawy}

Zgodnie z treścią art. 6 projektowanej ustawy, wina w organizacji będzie stanowiła podstawę odpowiedzialności podmiotu zbiorowego w dwóch sytuacjach. W pierwszej sytuacji konieczne jest łączne spełnienie następujących przesłanek:

1) popełniony czyn zabroniony pozostaje bezpośrednio $\mathrm{W}$ związku $\mathrm{z}$ działalnością prowadzoną przez podmiot zbiorowy,

2) czyn zabroniony został popełniony przez:

a) osobę fizyczną uprawnioną do reprezentowania podmiotu zbiorowego, podejmowania w jego imieniu decyzji lub sprawowania nadzoru, w związku z jej działaniem w interesie lub na rzecz tego podmiotu lub

b) osobę fizyczną dopuszczoną do działania przez organ podmiotu zbiorowego, członka jego organu lub osobę uprawnioną do jego reprezentowania, podejmowania w jego imieniu decyzji lub sprawowania nadzoru, wskutek nadużycia uprawnień lub niedopełnienia obowiązków lub

c) osobę zatrudnioną przez podmiot zbiorowy, w związku ze świadczeniem pracy na jego rzecz.

W drugiej sytuacji podmiot zbiorowy odpowiada za czyn zabroniony, z którego chociażby pośrednio osiągnął korzyść majątkową, jeżeli:

1) czyn został popełniony przez:

a) podwykonawcę albo innego przedsiębiorcę będącego osobą fizyczną, jeżeli jego czyn zabroniony pozostawał $\mathrm{w}$ związku $\mathrm{z}$ wykonywaniem umowy zawartej z podmiotem zbiorowym lub

b) pracownika albo osobę upoważnioną do działania w interesie lub na rzecz przedsiębiorcy niebędącego osobą fizyczną, jeżeli jego czyn pozostawał w związku $\mathrm{z}$ wykonywaniem umowy zawartej przez tego przedsiębiorcę z podmiotem zbiorowym,

\footnotetext{
${ }^{30}$ Artykuł 5 w zw. z art. 3 pkt 3a ustawy z 2002 r. w brzmieniu wprowadzonym ustawą z 29.7.2011 r. o zmianie ustawy - Kodeks karny, ustawy - Kodeks postępowania karnego oraz ustawy o odpowiedzialności podmiotów zbiorowych za czyny zabronione pod groźbą kary.
} 
2) organ, członek organu lub osoba uprawniona do reprezentowania podmiotu zbiorowego, podejmowania w jego imieniu decyzji lub sprawowania nadzoru, wiedziała lub przy zachowaniu ostrożności wymaganej w danych okolicznościach mogła się dowiedzieć, że wskazane powyżej osoby będą usiłowały popełnić lub popełniły czyn zabroniony lub że u przedsiębiorcy, zktórym zawarto umowę, występują nieprawidłowości w organizacji.

W każdej z powyższych sytuacji warunkiem odpowiedzialności podmiotu zbiorowego jest wyczerpanie znamion czynu zabronionego $\mathrm{w}$ następstwie winy $\mathrm{w}$ nadzorze lub winy organizacyjnej, rozumianej jako taka nieprawidłowość w organizacji działalności podmiotu zbiorowego, która ułatwiła lub umożliwiła popełnienie czynu zabronionego, chociaż inna organizacja działalności mogła zapobiec popełnieniu tego czynu. Generalna klauzula ułatwienia lub umożliwienia popełnienia czynu zabronionego poprzez sposób organizacji została przez ustawodawcę uzupełniona otwartym katalogiem sytuacji stanowiących taką nieprawidłowość:

1) brak określenia zasad postępowania na wypadek zagrożenia popełnienia czynu zabronionego lub skutków niezachowania reguł ostrożności, z wyjątkiem mikroprzedsiębiorców ${ }^{31}$, którzy nie są zobowiązani do określenia tych zasad,

2) brak określenia zakresu odpowiedzialności organów podmiotu zbiorowego, innych jego komórek organizacyjnych, jego pracowników lub osób uprawnionych do działania $\mathrm{w}$ jego imieniu lub interesie, $\mathrm{z}$ wyjątkiem mikroprzedsiębiorców, którzy nie są zobowiązani do określenia tych zasad,

3) brak określenia osoby lub komórki organizacyjnej nadzorującej przestrzeganie przepisów i zasad regulujących działalność podmiotu w podmiocie będącym co najmniej średnim przedsiębiorcą ${ }^{32}$,

4) organ podmiotu zbiorowego lub osoba fizyczna uprawniona do jego reprezentowania, podejmowania w jego imieniu decyzji lub sprawowania nadzoru, w związku z jej działaniem $\mathrm{w}$ interesie lub na rzecz tego podmiotu, wiedział o nieprawidłowości w organizacji, która ułatwiła lub umożliwiła popełnienie czynu zabronionego.

Wskazane nieprawidłowości mają być oceniane $\mathrm{z}$ uwzględnieniem zasady proporcjonalności. Podmiot zbiorowy nie będzie ponosił odpowiedzialności za nieprawidłowość w organizacji, jeżeli wykaże, że wszystkie organy i osoby uprawnione

\footnotetext{
${ }^{31} \mathrm{~W}$ ustawie mowa o mikroprzedsiębiorcach w rozumieniu art. 7 ust. 1 pkt 1 ustawy z 6.3.2018 r. - Prawo przedsiębiorców, Dz. U. z 2018 r., poz. 2212.

${ }^{32} \mathrm{~W}$ rozumieniu art. 7 ust. 1 pkt 3 ustawy z 6.3.2018 r. - Prawo przedsiębiorców.
} 
do działania w jego imieniu lub interesie zachowały należytą staranność wymaganą w danych okolicznościach w organizacji działalności tego podmiotu oraz w nadzorze nad tą działalnością.

\section{Ocena projektowanych regulacji}

Wydaje się, że stosowanie w praktyce powyższych zasad nastręczy wiele trudności zarówno podmiotom, które będą chciały wdrożyć w swoich przedsiębiorstwach rozwiązania mające na celu minimalizację ryzyka pociągnięcia do odpowiedzialności z tytułu winy w organizacji, jak również dla organów ścigania oraz sądów. W mojej ocenie, do celu wykładni pojęcia nieprawidłowości w organizacji przydatne może być porównanie sposobu organizacji podmiotu zbiorowego ze swoistym modelem ,prawidłowego" sposobu organizacji dla danego podmiotu zbiorowego, z uwzględnieniem jego rozmiaru i przedmiotu działalności, podobnie jak ma to miejsce w przypadku wykładni pojęcia należytej staranności. Taki sposób interpretacji wydaje się sugerować sama ustawa, zwalniając $\mathrm{z}$ odpowiedzialności za nieprawidłowość w organizacji podmiot, którego wszystkie organy i osoby uprawnione do działania w jego imieniu lub interesie zachowały należytą staranność. Nie zmienia to jednak faktu, że tworzenie modelu „należytej organizacji” może być kłopotliwe, ponieważ w pierwszej kolejności wymaga określenia optymalnej, z punktu widzenia zapobiegania naruszeniom przepisów prawa, struktury organizacyjnej podmiotu zbiorowego, a następnie oceny związku między sposobem organizacji podmiotu zbiorowego a możliwością lub łatwością popełnienia czynu zabronionego.

Określenie optymalnej struktury organizacyjnej, adekwatnej do rozmiaru i przedmiotu działalności podmiotu zbiorowego, w wielu przypadkach może stanowić wiedzę specjalistyczną, a tym samym rodzić potrzebę powołania biegłych. Wyzwaniem może być jednak nawet określenie, jaką wiedzę i doświadczenie winien posiadać biegły dokonujący analizy struktury organizacyjnej podmiotu zbiorowego pod kątem ewentualnych nieprawidłowości - czy winien to być konsultant biznesowy specjalizujący się w danej branży? Czy dopuszczalne byłoby dokonywanie oceny struktury organizacyjnej podmiotu zbiorowego przez porównanie ze strukturą organizacyjną jego konkurenta? A jeśli tak, jaka byłaby podstawa prawna do uzyskiwania przez organy władzy państwowej wiedzy na temat szczegółów organizacji wewnętrznej konkurencyjnego przedsiębiorstwa, z dużym prawdopodobieństwem objętych tajemnicą przedsiębiorstwa? 
Alternatywnym podejściem mogłaby być próba utworzenia przez doktrynę i orzecznictwo otwartego katalogu przesłanek stanowiących o nieprawidłowościach w organizacji podmiotu zbiorowego, swoistego rozszerzenia katalogu ustawowego, obejmującego na przykład: brak pisemnych regulacji wewnętrznych, nieprzestrzeganie specyficznych dla rodzaju przedsiębiorstwa zasad bezpieczeństwa i higieny pracy, brak określenia zakresu obowiązków osób zatrudnionych, brak zasad zarządzania konfliktami interesów, brak kontroli, brak zasad zapobiegania korupcji, negatywne wyniki audytu. Jednak i w tym wypadku konieczna byłaby specjalistyczna ocena, czy ilość, skala, waga oraz skutki zidentyfikowanych nieprawidłowości są takiej natury, że umożliwiły lub ułatwiły popełnienie czynu zabronionego. Przykładowo, nawet w liczącym kilkadziesiąt osób przedsiębiorstwie brak pisemnych procedur niekoniecznie musiałby zostać uznany za ułatwiający popełnienie czynu zabronionego, jeżeli w tym zakresie istnieją niesformalizowane zasady postępowania.

Równie skomplikowanym zagadnieniem wydaje się być ocena związku między sposobem organizacji podmiotu zbiorowego a możliwością lub łatwością popełnienia czynu zabronionego. Czy można rozstrzygać o niedostatecznej kulturze raportowania o nieprawidłowościach $\mathrm{w}$ sytuacji, gdy w danej sytuacji przełożonego nie powiadomiono o nietypowym zachowaniu jednego z pracowników, który - w świetle ustaleń dokonanych post factum - czynił przygotowania do popełnienia czynu zabronionego? Czy w sytuacji, kiedy do wykonywania obowiązków wymagających wysoce specjalistycznej wiedzy z uwagi na wielkość i skalę działania przedsiębiorstwa wystarczające jest zatrudnienie tylko jednego pracownika, pracodawca winien dokonać podziału etatu między dwie osoby celem umożliwienia wykonywania kontroli na tzw. drugą rękę?

Analiza dosyć ogólnikowo sformułowanego przez ustawodawcę katalogu przykładowych nieprawidłowości organizacyjnych niestety nie daje odpowiedzi na wyżej postawione pytania. Moim zdaniem, najłatwiejszą w stosowaniu przesłanką odpowiedzialności wydaje się być wiedza organu podmiotu zbiorowego lub osoby uprawnionej do jego reprezentowania, podejmowania $\mathrm{w}$ jego imieniu decyzji lub sprawowania nadzoru o nieprawidłowości w organizacji, która ułatwiła lub umożliwiła popełnienie czynu zabronionego. W zakres normowania tej przesłanki mogłaby, jak sądzę, wchodzić posiadana przez zarząd spółki informacja o luce bezpieczeństwa w systemach informatycznych czy powtarzające się zgłoszenia o nieprawidłowościach w fakturowaniu otrzymywane od kontrahentów. Jeżeli osoby odpowiedzialne, mimo posiadania takiej wiedzy, nie podejmują żadnych działań mających na celu eliminację nieprawidłowości, można mówić o quasi-zamiarze ewentualnym. Trudno jednak jednoznacznie rozstrzygać, czy przedmiotowa 
przesłanka mogłaby stanowić podstawę odpowiedzialności podmiotu zbiorowego w przytoczonym wyżej przykładzie ryzyka nadużyć dokonanych przez jedynego pracownika posiadającego wysoko specjalistyczną wiedzę $\mathrm{W}$ danym temacie, $\mathrm{z}$ uwagi na to, że merytoryczne podstawy jego decyzji nie są weryfikowane przez żadną inną osobę.

W ustawowym katalogu nieprawidłowości w organizacji zwraca również uwagę uzależnienie możliwości ich stosowania od rozmiaru przedsiębiorcy, mogące stanowić asumpt do refleksji nad tym, czy nie stanowią one swoistego obowiązku dla przedsiębiorcy pragnącego zminimalizować ryzyko pociągnięcia do odpowiedzialności na podstawie projektowanych przepisów. W szczególności ustawa wydaje się sugerować, że średni i duzi przedsiębiorcy powinni ustanowić osobę lub komórkę organizacyjną odpowiedzialną za nadzór nad przestrzeganiem przepisów i zasad regulujących działalność podmiotu, zaś wszyscy przedsiębiorcy, za wyjątkiem mikroprzedsiębiorców, winni określić zakres odpowiedzialności swoich organów, komórek organizacyjnych, pracowników lub osób uprawnionych do działania w swoim imieniu lub interesie oraz zasady postępowania na wypadek zagrożenia popełnienia czynu zabronionego lub skutków niezachowania reguł ostrożności - w przeciwnym razie, w wypadku popełnienia czynu zabronionego przez podmiot wskazany w art. 5 ust. 2 lub art. 6 ust. 1 lub 2 projektowanej ustawy, trudno byłoby im dowieść dochowania należytej staranności.

W razie uznania, że ustawowy katalog nieprawidłowości w organizacji ustanawia quasiobowiązki organizacyjne, w tym sensie, że sankcjonowany nie jest sam w sobie brak ich realizacji, lecz brak ich realizacji w sytuacji popełnienia czynu zabronionego przez osobę działającą w imieniu przedsiębiorstwa lub na jego rzecz, pojawia się jednak pytanie o sposób realizacji tychże obowiązków - czy całokształt mechanizmów kontroli wewnętrznej w organizacji może zostać uznany za ,zasady postępowania na wypadek zagrożenia popełnienia czynu zabronionego lub skutków niezachowania reguł ostrożności” czy też chodzi o określenie dodatkowego zbioru zasad postępowania na wypadek naruszenia istniejących zasad i nieskuteczności mechanizmów kontrolnych? Czy w celu oceny prawidłowości mechanizmów kontrolnych uzasadnione będzie powoływanie się na międzynarodowe standardy w zakresie kontroli wewnętrznej, takie jak $\mathrm{COSO}^{33}$ ? Jak ocenić sytuację, w której wszystkie organy, jednostki organizacyjne, pracownicy przedsiębiorstwa mają określone zakresy odpowiedzialności, jednak w sposób niespójny z zakresem realnie wykonywanych

\footnotetext{
${ }^{33}$ Standard opracowany przez Komitet Organizacji Sponsorujących Komisję Treadway.
} 
przez nich czynności, wskutek czego pracownik jest formalnie odpowiedzialny za osiągnięcie rezultatu, na który nie posiada wpływu lub posiada nikły wpływ?

\section{Porównanie projektowanych regulacji ze standardami konstytucyjności odpowiedzialności podmiotu zbiorowego za zawinienie organizacyjne określonymi w wyroku TK z 3.11.2004 r., K 18/03}

Jak wskazano powyżej, na gruncie obecnie obowiązującej ustawy podmiot zbiorowy podlega odpowiedzialności, jeżeli do popełnienia czynu zabronionego doszło w następstwie takiej organizacji działalności podmiotu zbiorowego, która nie zapewniała uniknięcia popełnienia czynu zabronionego przez osobę fizyczną działającą w imieniu lub w interesie podmiotu zbiorowego w ramach uprawnienia lub obowiązku do jego reprezentowania, podejmowania $\mathrm{w}$ jego imieniu decyzji lub wykonywania kontroli wewnętrznej albo przy przekroczeniu tego uprawnienia lub niedopełnieniu tego obowiązku lub przez osobę fizyczną będącą przedsiębiorcą, która bezpośrednio współdziałała z podmiotem zbiorowym w realizacji celu prawnie dopuszczalnego, podczas gdy mogło je zapewnić zachowanie należytej staranności, wymaganej $\mathrm{w}$ danych okolicznościach, przez organ lub przedstawiciela podmiotu zbiorowego. Jak podkreślają jednak A. Krawczyk, A. Gisman, stosunkowo łatwym sposobem uniknięcia odpowiedzialności na tej podstawie jest wdrażanie przez przedsiębiorstwa systemów criminal compliance ${ }^{34}$, ponieważ ,wprowadzenie takiego systemu niewątpliwie świadczy o stworzeniu ram organizacyjnych, których celem jest zapobieżenie popełnianiu przestępstw w przedsiębiorstwie".

Najbardziej rzucającą się w oczy różnicą w sposobie określenia winy w organizacji na gruncie obowiązujących oraz projektowanych przepisów o odpowiedzialności podmiotów zbiorowych jest brak katalogu nieprawidłowości w obecnie obowiązującej ustawie, który, jak wskazano powyżej, w wersji projektowanej budzi wiele wątpliwości interpretacyjnych. Natomiast w zakresie sformułowania przesłanki winy w organizacji należy wskazać, że w obecnym stanie prawnym ,przesłanką ekskulpacyjną jest taka organizacja podmiotu zbiorowego, która jest w stanie zapobiec popełnieniu czynu zabronionego przez osoby wymienione $\mathrm{w}$ art. 3 pkt 1 u.o.p.z. lub przedsiębiorcę bezpośrednio współdziałającego w realizacji celu prawnie dopuszczalnego, podczas gdy można było mu zapobiec przez

\footnotetext{
34 A. Gisman, A. Krawczyk, Criminal compliance jako środek zapobiegania odpowiedzialności podmiotów zbiorowych za czyny zabronione pod groźba kary, „Monitor Prawa Handlowego”, 2015, nr 1, s. 7 i n.
} 
zachowanie należytej staranności przez organ lub przedstawiciela podmiotu zbiorowego"35, podczas gdy w projektowanej ustawie mowa o ,nieprawidłowości w organizacji działalności podmiotu zbiorowego, która ułatwiła lub umożliwiła popełnienie czynu zabronionego, chociaż inna organizacja działalności mogła zapobiec popełnieniu tego czynu"36. Porównując te dwa sformułowania, warto zauważyć, że skoro obecnie obowiązująca ustawa sankcjonuje (oczywiście po spełnieniu dodatkowych warunków, w tym przede wszystkim prawomocnym stwierdzeniem karalności zindywidualizowanego sprawcy) sposób organizacji działalności podmiotu zbiorowego, która „nie zapewniała uniknięcia popełnienia czynu zabronionego (...) podczas gdy można było mu zapobiec przez zachowanie należytej staranności”, to od przedsiębiorcy wymagane jest zachowanie należytej staranności, w tym w szczególności dokonanie wysiłków w celu wdrożenia mechanizmów kontrolnych. Ocenie podlega staranność działania, a nie rezultat (tj. brak efektywności mechanizmów kontrolnych), dlatego uzasadnione jest stwierdzenie, że implementacja systemu criminal compliance jest skutecznym środkiem umożliwiającym uniknięcie pociągnięcia do odpowiedzialności.

Projektowana ustawa, z uwagi na brzmienie przesłanki „chociaż inna organizacja mogła zapobiec popełnieniu tego czynu”, zadaje się natomiast zakładać konieczność dokonania przez sąd porównania pomiędzy faktycznym sposobem organizacji przedsiębiorstwa a swoistym wzorcem organizacji. Rozbieżności pomiędzy tymi dwoma modelami będą podlegały ocenie z punktu widzenia ułatwienia lub umożliwienia popełnienia czynu zabronionego, co było sygnalizowane powyżej. Również w tym wypadku przesłanką ekskulpacyjną jest dochowanie należytej staranności, jednak wydaje się, że na gruncie projektowanych przepisów będzie ona rozumiana bardziej rygorystycznie. Po pierwsze dlatego, że ciężar jej wykazania ma spoczywać na przedsiębiorcy (art. 6 ust. 6 projektowanej ustawy), po drugie zaś wdrożenie systemu kontroli wewnętrznej lub criminal compliance, spełniającego wymogi należytej staranności w rozumieniu obecnej ustawy, może nie być wystarczające na potrzeby dokonania wspomnianego porównania z wzorcowym modelem organizacji.

Jak wspomniano, w wyroku z 3.11.2004 r., sygn. akt K 18/03 TK uznał, że przepis ustanawiający odpowiedzialność podmiotu zbiorowego za nieodpowiednią organizację, której skutkiem jest popełnienie czynu zabronionego przez osobę fizyczną będącą przedsiębiorcą oraz rzeczywista lub potencjalna korzyść o charakterze majątkowym

\footnotetext{
35 D. Habrat, Odpowiedzialność podmiotów zbiorowych za czyny zabronione pod groźba kary. Komentarz, Warszawa 2014, s. 38 - 39.

${ }^{36}$ Artykuł 6 ust. 3 pkt 2 projektowanej ustawy.
} 
lub niemajątkowym dla podmiotu zbiorowego, prowadzi do zobiektywizowania odpowiedzialności podmiotu zbiorowego, co jest niezgodne z zasadą winy, będącą warunkiem możliwości przypisania odpowiedzialności o charakterze represyjnym $\mathrm{w}$ demokratycznym państwie prawnym. W świetle tych kryteriów można podjąć próbę rozważenia, czy projektowany model odpowiedzialności podmiotu zbiorowego $\mathrm{W}$ zakresie winy organizacyjnej spełnia standardy konstytucyjności określone przez TK w powyższym orzeczeniu.

W mojej ocenie, bardzo obszerny katalog podmiotów, za których działanie może ponieść odpowiedzialność podmiot zbiorowy, rodzi ryzyko przypisania mu odpowiedzialności za czyny zabronione, których uniknięcie byłoby ewentualnie możliwe jedynie w wypadku wprowadzenia ponadstandardowych i mocno obciążających (czasowo oraz kosztowo) środków kontroli. Przykładem takiej sytuacji może być nieuprawnione (niezgodne z zakresem zawartej umowy $^{37}$ i otrzymanym upoważnieniem) przetwarzanie $^{38}$ danych osobowych ${ }^{39}$ klientów administratora $^{40}$ (podmiotu zbiorowego) przez pracownika podmiotu przetwarzającego ${ }^{41}$ (np. ich profilowanie ${ }^{42}$ ), z którego administrator uzyskuje korzyść w postaci pogłębionej wiedzy na temat preferencji swoich klientów, co pozwala mu na lepsze dopasowanie oferty produktowej i reklam. W kontekście ewentualnej winy organizacyjnej administratora należy zauważyć, że w takim wypadku zapewne byłoby możliwe zapobieżenie popełnieniu temu czynu poprzez niepowierzanie przetwarzania danych podmiotowi trzeciemu, ograniczenie zakresu przetwarzanych danych, wykonywanie częstszych lub bardziej szczegółowych audytów, jednakże celem regulacji z zakresu ochrony danych osobowych nie jest nałożenie na administratorów danych ograniczeń niepozwalających na normalne prowadzenie działalności gospodarczej ${ }^{43}$.

Analogiczną sytuacją byłoby niestosowanie wymaganych przepisami prawa zabezpieczeń przez pracowników podwykonawcy realizującego projekt budowlany, dzięki któremu główny wykonawca (podmiot zbiorowy) odnosi korzyść w postaci niższych kosztów umowy. Przejawem staranności wykonawcy byłoby w takim wypadku zawarcie

\footnotetext{
${ }^{37}$ Umowy, o której mowa w art. 28 ust. 3 rozporządzenia Parlamentu Europejskiego i Rady (UE) 2016/679 z dnia 27.4.2016 r. w sprawie ochrony osób fizycznych w związku z przetwarzaniem danych osobowych i w sprawie swobodnego przepływu takich danych oraz uchylenia dyrektywy 95/46/WE (ogólne rozporządzenie o ochronie danych), Dz.UE. L 119 z 4.5.2016 r. s. 1-88, dalej: „RODO”.

${ }^{38} \mathrm{~W}$ rozumieniu art. 4 pkt 2 RODO.

${ }^{39} \mathrm{~W}$ rozumieniu art. 4 pkt 1 RODO.

${ }^{40} \mathrm{~W}$ rozumieniu art. 4 pkt 7 RODO.

${ }^{41} \mathrm{~W}$ rozumieniu art. 4 pkt 8 RODO.

${ }^{42} \mathrm{~W}$ rozumieniu art. 4 pkt 4 RODO.

${ }^{43}$ Por. motyw 4 i motyw 6 RODO.
} 
w umowie z podwykonawcą zapisów zobowiązujących podwykonawcę do stosowania tych zabezpieczeń. Czy jednak dla zachowania należytej staranności wystarczające byłoby wskazanie w umowie, że podwykonawca zobowiązany jest podczas wykonywania przedmiotu umowy do przestrzegania powszechnie obowiązujących przepisów prawa? Czy konieczne jest wskazywanie wprost w umowie wszystkich wymaganych zabezpieczeń i zastrzeganie kar umownych na wypadek ich niestosowania? Czy wreszcie wykonawca winien cyklicznie weryfikować fakt stosowania zabezpieczeń poprzez fizyczną obecność na terenie budowy?

Powyższe pytania ilustrują, że w niemal każdej sytuacji podmiot zbiorowy mógłby podjąć dodatkowe wysiłki, które utrudniłyby lub uniemożliwiły popełnienie czynu zabronionego. Wysiłki te jednak nie powinny być nieproporcjonalne w tym sensie, że nie mogą utrudniać lub uniemożliwiać prowadzenia działalności gospodarczej. Tymczasem w szczególności przerzucenie ciężaru dowodzenia wykazania należytej staranności na podmiot zbiorowy (art. 16 ust. 6 projektowanej ustawy) rodzi ryzyko stawiania im nierealistycznych w biznesowej rzeczywistości wymogów.

Innego rodzaju sytuacją mogłoby być wykorzystanie przez pracownika lub osobę reprezentującą podmiot zbiorowy prywatnych kontaktów z osobą odpowiedzialną za ocenę ofert nadesłanych w ramach przetargu lub konkursu organizowanego przez inny podmiot, aby zapewnić wygraną podmiotu zbiorowego w tym postępowaniu. O ile nie budzi wątpliwości słuszność ukarania osoby odpowiedzialnej za ocenę ofert za niezachowanie wymaganego obiektywizmu, o tyle można się zastanawiać, jakie cele społeczne realizowałoby karanie podmiotu zbiorowego za niewystarczające przeszkolenie lub weryfikowanie przestrzegania standardów antykorupcyjnych.

W mojej ocenie, zarówno trzy powyższe jak i inne wskazane w niniejszym artykule przykłady i pytania świadczą o tym, że przyjęty w projektowanej ustawie model odpowiedzialności podmiotów zbiorowych jest na tyle szeroki, że może prowadzić do przypisania podmiotowi zbiorowemu odpowiedzialności na zasadzie ryzyka, a tym samym obiektywizacji zasad jego odpowiedzialności, która to została uznana przez Trybunał Konstytucyjny za sprzeczną z konstytucyjnymi wymogami ustanawiania przepisów o charakterze represyjnym. Wprowadzenie zasady proporcjonalności nie wydaje się być wystarczającym zabezpieczeniem dla podmiotów zbiorowych, zwłaszcza w sytuacji obciążenia ich obowiązkiem dowodzenia zachowania przez siebie należytej staranności. 


\section{Podsumowanie}

Podsumowując, projektowana ustawa o odpowiedzialności podmiotów zbiorowych stanowi kolejną próbę ugruntowania w polskim porządku prawnym stosunkowo nową podstawę odpowiedzialności, jaką jest wina w organizacji. Choć przesłanka ta istnieje już na gruncie obecnie obowiązujących przepisów ustawy z 28.10.2002 r. o odpowiedzialności podmiotów zbiorowych za czyny zabronione pod groźbą kary, to jednak nie została jeszcze dogłębnie przeanalizowana z uwagi na niewielką liczbę postępowań sądowych prowadzonych na jej podstawie. Przesłanka w projektowanym brzmieniu wydaje się stawiać przedsiębiorcom bardziej rygorystyczne wymogi w zakresie zachowania należytej staranności. Budzi ona znaczące wątpliwości interpretacyjne, jedynie potęgowane przez proponowany przez ustawodawcę otwarty katalog nieprawidłowości w organizacji, stanowiący novum. Jest to stan zdecydowanie niepożądany, zarówno z punktu widzenia przedsiębiorców, którzy będą chcieli zabezpieczyć się przed ryzykiem pociągnięcia do odpowiedzialności, jak i organów ścigania oraz sądów, które mogą nie dysponować wystarczającą wiedzą ani instrumentarium prawnym, by dokonywać oceny prawidłowości organizacji podsądnych oraz związku pomiędzy ewentualnymi nieprawidłowościami a popełnieniem czynu zabronionego. Nadto w świetle zasad stanowienia przepisów o charakterze represyjnym w stosunku do podmiotów zbiorowych, określonych przez TK w wyroku z 3.11.2004 r., sygn. akt K 18/03, projektowane przepisy wydają się naruszać konstytucyjne standardy poprzez oparcie zasad odpowiedzialności podmiotów zbiorowych na zasadzie ryzyka. 


\section{Organisational blameworthiness as a basis of collective entity's responsibility in the light of drafted Act on Collective Entities' Responsibility \\ Summary \\ Drafted Act on Collective Entities' Responsibility introduces organisational blameworthiness as a relatively new basis of responsibility into the Polish legal system. What is being alternated in comparison with the law currently being in force are the premises of deeming company's organization improper. Another important novum is an open catalogue of sample malfunctions which deepens interpretational doubts regarding the concept of organisational blameworthiness. A comparison of company's organization with an abstract model of "due" organization for a specific collective entity, taking into consideration its scale and area of business activity could serve as a useful tool in process of interpretation of concept of organisational blameworthiness, similarly as during an assessment of due care. Nevertheless, creation of such a model might occur troublesome since it requires: firstly, determining a "proper" (for a purpose of minimizing a risk of non-compliance) organizational structure of collective entity and secondly, assessment of a relationship between collective entity's organisation and possibility or simplicity of committing a criminal offence.}

\section{Ida Jóźwiak}

Absolwentka Uniwersytetu Jagiellońskiego (kierunek prawo), doktorantka w Katedrze Prawa Gospodarczego Prywatnego WPiA UKSW w Warszawie (kierunek prawo), gdzie pracuje nad rozprawą na temat zarządzania konfliktami interesów w spółkach publicznych. Zawodowo zajmuje się dynamicznie rozwijającą się branżą compliance. 